\title{
Role of Tuber Developmental Processes in Response of Potato to High Temperature and Elevated $\mathrm{CO}_{2}$
}

\author{
Chien-Teh Chen ${ }^{1}$ (D) and Tim L. Setter ${ }^{2, * \mathbb{D}}$ \\ 1 Department of Agronomy, National Chung Hsing University, Taichung 402, Taiwan; \\ ctchen41@dragon.nchu.edu.tw \\ 2 Section of Soil and Crop Sciences, School of Integrative Plant Science, Cornell University, Ithaca, NY 14853, USA \\ * Correspondence: TLS1@cornell.edu
}

Citation: Chen, C.-T.; Setter, T.L. Role of Tuber Developmental Processes in Response of Potato to High Temperature and Elevated $\mathrm{CO}_{2}$. Plants 2021, 10, 871. https://doi.org/ $10.3390 /$ plants 10050871

Academic Editor: James Bunce

Received: 11 April 2021

Accepted: 24 April 2021

Published: 26 April 2021

Publisher's Note: MDPI stays neutral with regard to jurisdictional claims in published maps and institutional affiliations.

Copyright: (c) 2021 by the authors. Licensee MDPI, Basel, Switzerland. This article is an open access article distributed under the terms and conditions of the Creative Commons Attribution (CC BY) license (https:// creativecommons.org/licenses/by/ $4.0 /)$.
Abstract: Potato is adapted to cool environments, and there is concern that its performance may be diminished considerably due to global warming and more frequent episodes of heat stress. Our objectives were to determine the response of potato plants to elevated $\mathrm{CO}_{2}(700 \mu \mathrm{mol} / \mathrm{mol})$ and high temperature $\left(35 / 25^{\circ} \mathrm{C}\right)$ at tuber initiation and tuber bulking, and to elucidate effects on sink developmental processes. Potato plants were grown in controlled environments with treatments at: Tuber initiation (TI), during the first two weeks after initiating short-day photoperiods, and Tuber bulking (TB). At TI, and $25{ }^{\circ} \mathrm{C}$, elevated $\mathrm{CO}_{2}$ increased tuber growth rate, while leaves and stems were not affected. Whole-plant dry matter accumulation rate, was inhibited by high temperature about twice as much at TI than at TB. Elevated $\mathrm{CO}_{2}$ partially ameliorated high temperature inhibition of sink organs. At TI, with $25{ }^{\circ} \mathrm{C}$, elevated $\mathrm{CO}_{2}$ primarily affected tuber cell proliferation. In contrast, tuber cell volume and endoreduplication were unaffected. These findings indicate that the TI stage and cell division is particularly responsive to elevated $\mathrm{CO}_{2}$ and high temperature stress, supporting the view that attention should be paid to the timing of high-temperature stress episodes with respect to this stage.

Keywords: Solanum tuberosum; tuber; sink organ; ambient temperature; cell proliferation

\section{Introduction}

Atmospheric $\mathrm{CO}_{2}$ levels and average global temperature have risen in the last decades and earth air temperature is predicted to continue to increase as a result of the rise in the levels of $\mathrm{CO}_{2}$ and other greenhouse gases [1,2]. While it is recognized that these trends will impact crop production and food security [3], crop growth models of potato (Solanum tuberosum) response to environmental variables, suggest that our understanding of the effects of elevated atmospheric $\mathrm{CO}_{2}$ and temperature remains far from complete and in need of improvement [4]. Findings from eight global climate models that were used to simulate potato agronomic and climate responses indicate that model variation was modest for predicted $\mathrm{CO}_{2}$ but was particularly uncertain for temperature [5]. Furthermore, climate predictions indicate that accompanying an increase in global average temperatures of $1.5^{\circ} \mathrm{C}$, will be a sharp rise in the likelihood of extreme heat stress events [6].

Atmospheric $\mathrm{CO}_{2}$ enrichment can affect potato growth and productivity by directly increasing leaf photosynthesis, in accordance with leaf photosynthetic $\mathrm{CO}_{2}$ response, and also by eliciting partial stomatal closing and increasing water use efficiency [7-9]. In addition, altered rates of photosynthate availability can modify partitioning of photosynthate among plant parts, which in turn can have feedback effects on photosynthesis [10-12]. These effects may lessen the potential benefit of elevated $\mathrm{CO}_{2}$ on potato photosynthesis, as has been found in season-long free air $\mathrm{CO}_{2}$ enrichment (FACE) $[11,13,14]$. In potato, elevated $\mathrm{CO}_{2}$ can lead to greater stimulation of tuber development than above-ground plant parts such that harvest index is increased [15]. 
Consistent with its Andean origin, potato is a heat-sensitive crop, which performs best at relatively cool temperatures [3]. For example, tuber dry matter partitioning in the temperate-adapted cultivar Katahdin was decreased $65 \%$ when day /night temperature was increased from $24 / 15^{\circ} \mathrm{C}(\mathrm{max} / \mathrm{min})$ to $30 / 21^{\circ} \mathrm{C}$ [16]. Increases in temperature have the potential of affecting growth and development in several ways. High temperature inhibits photosynthesis in potato, as is generally the case in cool-adapted C3 plants [17]. In support of this explanation, some studies have reported that above-ground temperature has a greater effect than either root or stolon temperature on tuber growth [18]. Moreover, studies to determine the cause of poor yield of heat-susceptible potato genotypes grown at high temperature suggest it is related to inhibited photosynthesis and insufficient availability of the transportable sugar, sucrose [19]. In addition, warm temperature can have direct effects that inhibit tuber initiation and growth [20,21], thereby diverting photosynthate from tubers to shoots $[15,22,23]$. High temperature in the tuber zone inhibits tuber development [24], and studies have indicated that below-ground high temperature has greater effects than above-ground temperature due to inhibition of tuber development and sink strength, which shifts partitioning to above-ground shoots [25]. Studies have indicated that the negative effects of high temperature on potato growth and yield is dependent on the growth stage and is especially great at the early stages of tuber growth [26].

Potato is adapted to relatively cool growing environments, and it has been predicted that its yield will diminish due to global warming and more frequent episodes of heat stress [3]. It is possible that elevated atmospheric $\mathrm{CO}_{2}$ concentration, may partially ameliorate negative effects of heat stress by enhancing photosynthesis and lessening negative effects on potato tuber growth. Our objectives were to determine the response of potato plants to elevated $\mathrm{CO}_{2}$ and high temperature treatment at tuber initiation and tuber bulking, and to elucidate effects on sink developmental processes, including tuber cell division and expansion, levels of sugars, and certain carbohydrate-metabolizing enzymes. Our findings indicate that cell proliferation is particularly responsive to elevated $\mathrm{CO}_{2}$ and high temperature treatment, and that elevated $\mathrm{CO}_{2}$ partially ameliorates the effects of high temperature.

\section{Results}

\subsection{The Effects of High Temperature and Elevated $\mathrm{CO}_{2}$ on Potato Plant Growth \\ 2.1.1. Tuber Initiation Stage}

Dry matter accumulation rate (DMAR) during each treatment period was estimated from the difference in dry matter of plants harvested at the onset of a treatment, and those harvested 2 weeks later at the conclusion of the treatment. At the tuber initiation stage, high temperature $\left(35^{\circ} \mathrm{C}\right)$ substantially decreased tuber growth compared to normal temperature $\left(25^{\circ} \mathrm{C}\right)$ in both low $\left(\mathrm{Low}_{\mathrm{CO}_{2}}\right)$ and elevated $\left(\mathrm{Elev}_{\mathrm{CO}_{2}}\right) \mathrm{CO}_{2}$ environments (Figure 1). High temperature under $\mathrm{Low}_{\mathrm{CO}_{2}}$ decreased tuber DMAR by $82 \%$, and had similar effects (about $60 \%$ decrease) on DMAR of leaves and stems. Under $\mathrm{Elev}_{\mathrm{CO}_{2}}$, high temperature decreased DMAR somewhat less: by $63 \%$ in tubers and by about $25 \%$ in leaves and stems. On a whole plant basis (sum of the three plant parts), high temperature decreased DMAR by 56 and $35 \%$ in plants at $\mathrm{Low}_{\mathrm{CO}_{2}}$ and $\mathrm{Elev}_{\mathrm{CO}_{2}}$, respectively (Table 1). In contrast to temperature, elevated $\mathrm{CO}_{2}$ provided distinctly greater benefit to tubers compared to other plant parts. Elevated $\mathrm{CO}_{2}$ at $25^{\circ} \mathrm{C}$ increased DMAR $60 \%$ in tubers, but did not affect DMAR in leaves and stems. At $35^{\circ} \mathrm{C}$, elevated $\mathrm{CO}_{2}$ appeared to increase DMAR, and thereby partially ameliorate high temperature inhibition, in all three plant parts, but did not achieve statistical significance $(p \leq 0.05)$.

\subsubsection{Tuber Bulking Stage}

At the tuber bulking stage, tuber growth predominated, as there was negligible leaf and stem growth (Figure 2). Elevated $\mathrm{CO}_{2}$ increased tuber DMAR about 30 to $40 \%$ at both temperatures (Figure 2), and this was reflected in whole plant DMAR (the sum of tuber, leaf and stem) (Table 1). Comparing across growth stages, high temperature had greater effects on whole plant DMAR (Table 1) at the tuber initiation stage than at the 
tuber bulking stage (overall about -45 and $-24 \%$, respectively). In contrast, the effects of elevated $\mathrm{CO}_{2}$ on whole-plant DMAR were fairly similar at the two stages. Elevated $\mathrm{CO}_{2}$ at $25{ }^{\circ} \mathrm{C}$ increased whole plant DMAR by $29 \%$ at tuber initiation and by $34 \%$ at tuber bulking. Given that whole plant DMAR is a measure of net whole-plant photosynthesis in excess of respiration, this indicates that elevated $\mathrm{CO}_{2}$ provided consistent benefit throughout these phases of development. The main difference for $\mathrm{CO}_{2}$ effects across development stages was the case with high temperature during tuber initiation, where elevated $\mathrm{CO}_{2}$ benefitted leaf and stem growth in addition to tuber growth, whereas only tubers benefitted at the tuber bulking stage. This suggests that growing plant parts have a development window within which they are capable of responding to improved photosynthate supply.

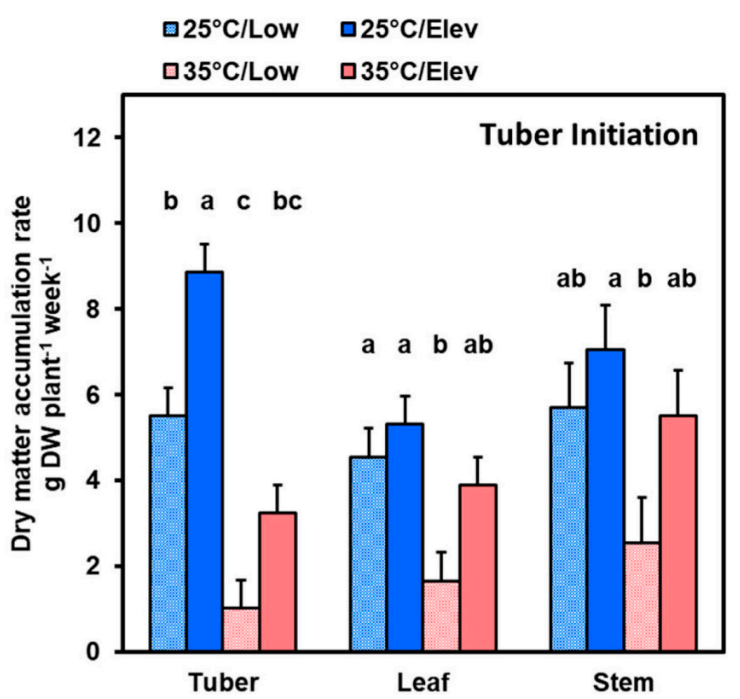

Figure 1. Tuber, leaf, and stem dry matter accumulation rate at the tuber initiation stage in plants that were given temperature $\left(25\right.$ or $\left.35^{\circ} \mathrm{C}\right)$ and $\mathrm{CO}_{2}\left(\mathrm{Low}_{\mathrm{CO}_{2}}\right.$ or $\left.\mathrm{Elev}_{\mathrm{CO}_{2}}\right)$ treatments during the 2-week tuber initiation period. To initiate tuberization, plants that were grown in long days were transferred to short-day growth chambers and exposed to treatments for 2 weeks, then harvested. Bars represent averages \pm SEM of 6 replicates; values labeled with different letters are significantly $(p \leq 0.05)$.

Table 1. Total plant dry-matter accumulation rate during temperature and $\mathrm{CO}_{2}$ treatments at the tuber initiation or tuber bulking stage. $\mathrm{CO}_{2}$ treatments were Low and Elevated (Elev). The pooled standard error of the design (SE) are shown $(n=6)$; values labeled with different letters are significantly $(p \leq 0.05)$ different.

\begin{tabular}{|c|c|c|c|c|c|}
\hline & \multicolumn{5}{|c|}{ Stage of Development } \\
\hline \multicolumn{2}{|c|}{ Treatment } & \multicolumn{4}{|c|}{ When Treatment Was Imposed } \\
\hline \multirow[t]{2}{*}{ temperature } & atm $\mathrm{CO}_{2}$ & Tuber Initiation & & Tuber Bulking & \\
\hline & & & & \multicolumn{2}{|c|}{ dry-matter accumulation rate } \\
\hline${ }^{\circ} \mathrm{C}$ & {$\left[\mathrm{CO}_{2}\right]$} & & \multicolumn{3}{|c|}{$\mathrm{g} \mathrm{DW} \mathrm{plant}^{-1} \mathrm{wk}^{-1}$} \\
\hline 25 & Elev & 24.3 & c & $\begin{array}{ll}1 & 37.7\end{array}$ & c \\
\hline 25 & Low & 18.9 & $\mathrm{cb}$ & 28.0 & $\mathrm{~b}$ \\
\hline 35 & Elev & 15.8 & ba & 31.9 & $\mathrm{cb}$ \\
\hline \multirow[t]{2}{*}{35} & Low & 8.3 & a & 19.0 & $\mathrm{a}$ \\
\hline & SE & 1.6 & & 1.8 & \\
\hline
\end{tabular}

\subsection{Tuber Numbers and Size}

High temperature at the tuber initiation stage substantially decreased the number of tubers per plant $\left(-37 \%\right.$ at $\mathrm{Low}_{\mathrm{CO}_{2}}$, and $-53 \%$ at $\mathrm{Elev}_{\mathrm{CO}_{2}}$ ) (Figure 3). Plants receiving treatments during tuber bulking were exposed to $25^{\circ} \mathrm{C}$ and Low $\mathrm{CO}_{2}$ during their tuber 
initiation stage, and they did not further increase their tuber numbers during tuber bulking. Hence, there were no treatment effects on tuber numbers at tuber bulking (Figure 3). Elevated $\mathrm{CO}_{2}$ did not affect tuber number at either stage. Histograms of the distribution of biomass among individual tubers at tuber initiation and tuber bulking, appeared to show that temperature $\times \mathrm{CO}_{2}$ treatment interactions affected the proportions of tubers in various size classes (Supplementary Figure S1).

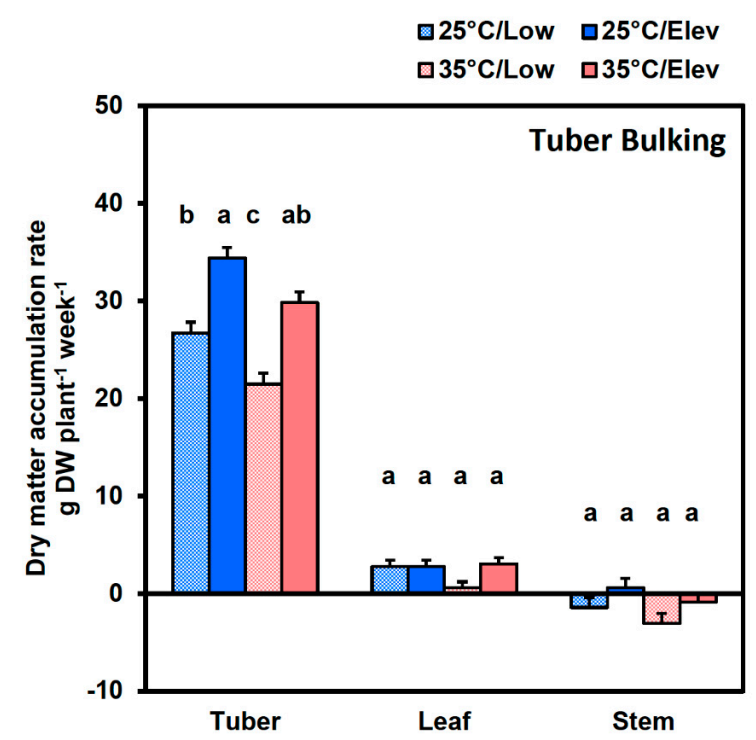

Figure 2. Tuber, leaf, and stem biomass accumulation rate at the tuber bulking stage following temperature $\left(25\right.$ or $\left.35^{\circ} \mathrm{C}\right)$ and $\mathrm{CO}_{2}\left(\mathrm{Low}_{\mathrm{CO}_{2}}\right.$ or $\left.\mathrm{Elev}_{\mathrm{CO}_{2}}\right)$ treatments during the 2 week tuber bulking stage. Plants were given two weeks of shortday conditions at $25{ }^{\circ} \mathrm{C}$ with low $\mathrm{CO}_{2}$ to induce tuberization, then maintained at short days and exposed to treatments for 2 weeks, and then harvested. Bars represent averages \pm SEM of 6 replicates; values labeled with different letters are significantly $(p \leq 0.05)$ different.

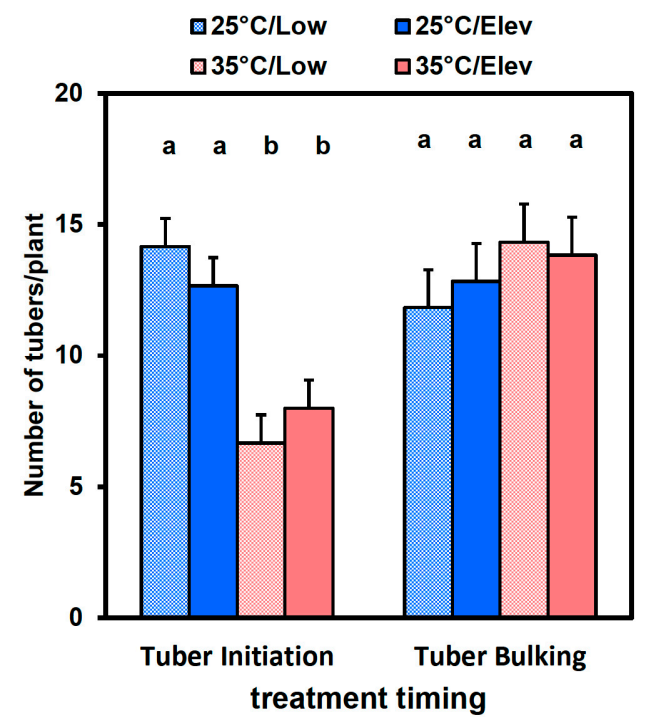

Figure 3. Tuber number in response to temperature $\left(25\right.$ or $\left.35^{\circ} \mathrm{C}\right)$ and $\mathrm{CO}_{2}\left(\mathrm{Low}_{\mathrm{CO}_{2}}\right.$ or $\left.\mathrm{Elev}_{\mathrm{CO}_{2}}\right)$ treatments at stages of tuber initiation and tuber bulking. Plants were harvested at 2 weeks after starting short-day exposure (tuber initiation period), or 4 weeks after starting short-day exposure and receiving temperature and $\mathrm{CO}_{2}$ treatments for the latter 2 weeks of the period (tuber bulking period). Tubers exceeding $1 \mathrm{~cm}$ diameter were counted. Bars represent averages \pm SEM of 6 replicates; values labeled with different letters are significantly $(p \leq 0.05)$ different. 


\subsection{The Effects of High Temperature and Elevated $\mathrm{CO}_{2}$ on Potato Tuber Cell Properties}

Given that plant growth responses to $\mathrm{CO}_{2}$ and temperature treatments primarily involved changes in tuber growth, we determined the extent to which each aspect of tuber growth was altered. Three aspects were evaluated: (1) cell division, which we evaluated by counting cell nuclei with flow cytometry; (2) cell expansion growth, which we evaluated by calculating average cell volume; and (3) post-mitotic DNA replication (endoreduplication), which we evaluated from the nuclear DNA analysis as the count of nuclei with DNA content $\geq 8 \mathrm{C}$ (where $\mathrm{C}$ is the haploid DNA content). The data in Figures 4 and 5 are shown as a proportion of the $\operatorname{Low}_{\mathrm{CO}_{2}} / 25^{\circ} \mathrm{C}$ control so that treatment effects on various tuber properties can be readily compared. At tuber initiation (Figure 4), high temperature substantially decreased tuber fresh weight, and correspondingly, total tuber cell number per plant. Elevated $\mathrm{CO}_{2}$ significantly $(p \leq 0.05)$ increased cell proliferation at $25^{\circ} \mathrm{C}$, while at $35^{\circ} \mathrm{C}$ the number of cells produced was very low and effects of elevated $\mathrm{CO}_{2}$ could not be discerned (Figure 4). In contrast, cell volume was not affected by $\mathrm{CO}_{2}$ and temperature treatments, except at high temperature and elevated $\mathrm{CO}_{2}$, where average cell volume was increased. The extent of endoreduplication, which reflects nuclear DNA reduplication in the absence of intervening mitosis, was not affected by treatments. Similarly, at tuber bulking (Figure 5), elevated $\mathrm{CO}_{2}$ and high temperature affected cell proliferation in some treatment combinations, and at elevated $\mathrm{CO}_{2}$ and temperature cell volume increased; however, the magnitude of treatment effects was less than during tuber initiation.

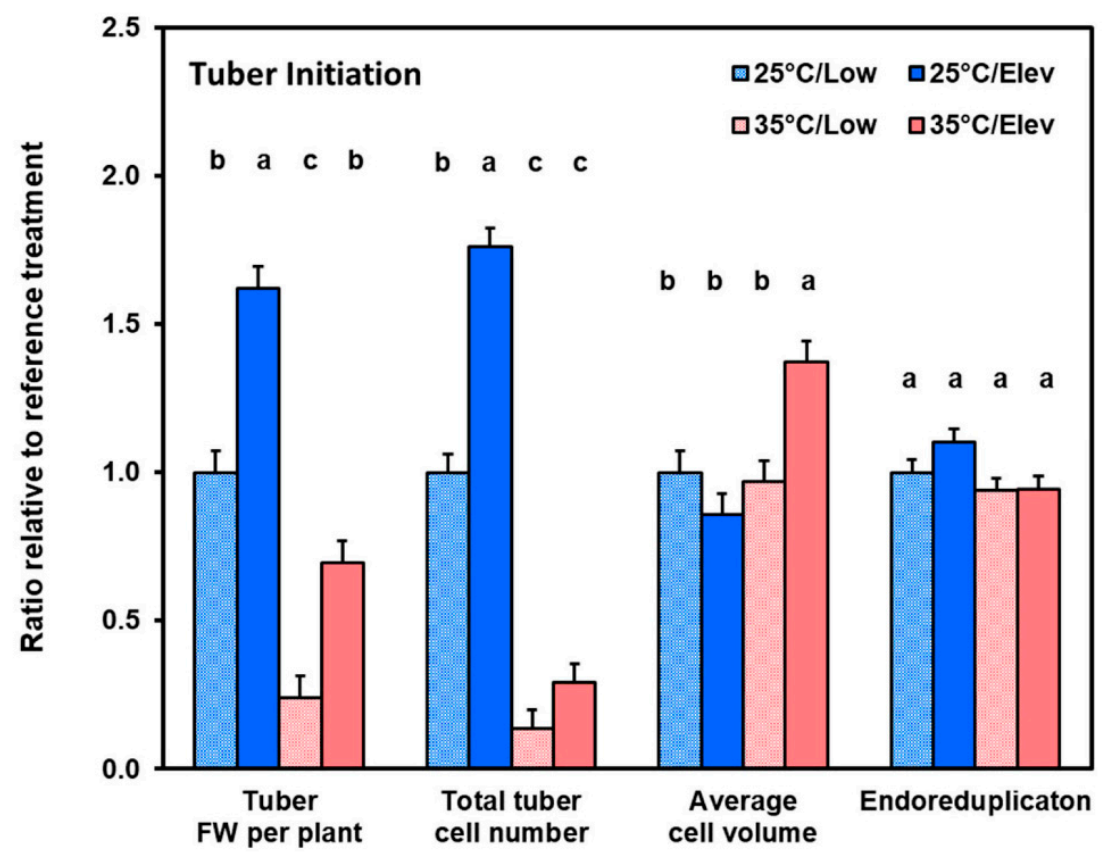

Figure 4. Relative increase in tuber properties with respect to $25^{\circ} \mathrm{C} / \mathrm{Low}_{\mathrm{CO}_{2}}$ control in response to temperature $\left(25\right.$ or $\left.35{ }^{\circ} \mathrm{C}\right)$ or $\mathrm{CO}_{2}$ treatments $\left(\mathrm{Low}_{\mathrm{CO}_{2}}\right.$ or $\left.\mathrm{Elev}_{\mathrm{CO}_{2}}\right)$ at the tuber initiation stage. Tuber weight and tuber cell number were summed for each plant and represent the increments of tuber fresh-weight growth and cell proliferation during the treatment periods. Data are expressed relative to the $25^{\circ} \mathrm{C} / \mathrm{Low}_{\mathrm{CO}_{2}}$ reference which was: $80.5 \mathrm{~g}$ tuber fresh weight plant ${ }^{-1}, 1.25 \times 10^{8}$ tuber cells plant ${ }^{-1}, 7.9 \times 10^{5} \mu^{3}$ average tuber cell volume, and $31.3 \%$ average proportion of tuber cells in endoreduplication categories ( $\geq 8 \mathrm{C}$ nuclear DNA content). See Materials and Methods for details. Bars represent averages \pm SEM of 6 replicates; values labeled with different letters are significantly $(p \leq 0.05)$ different. 


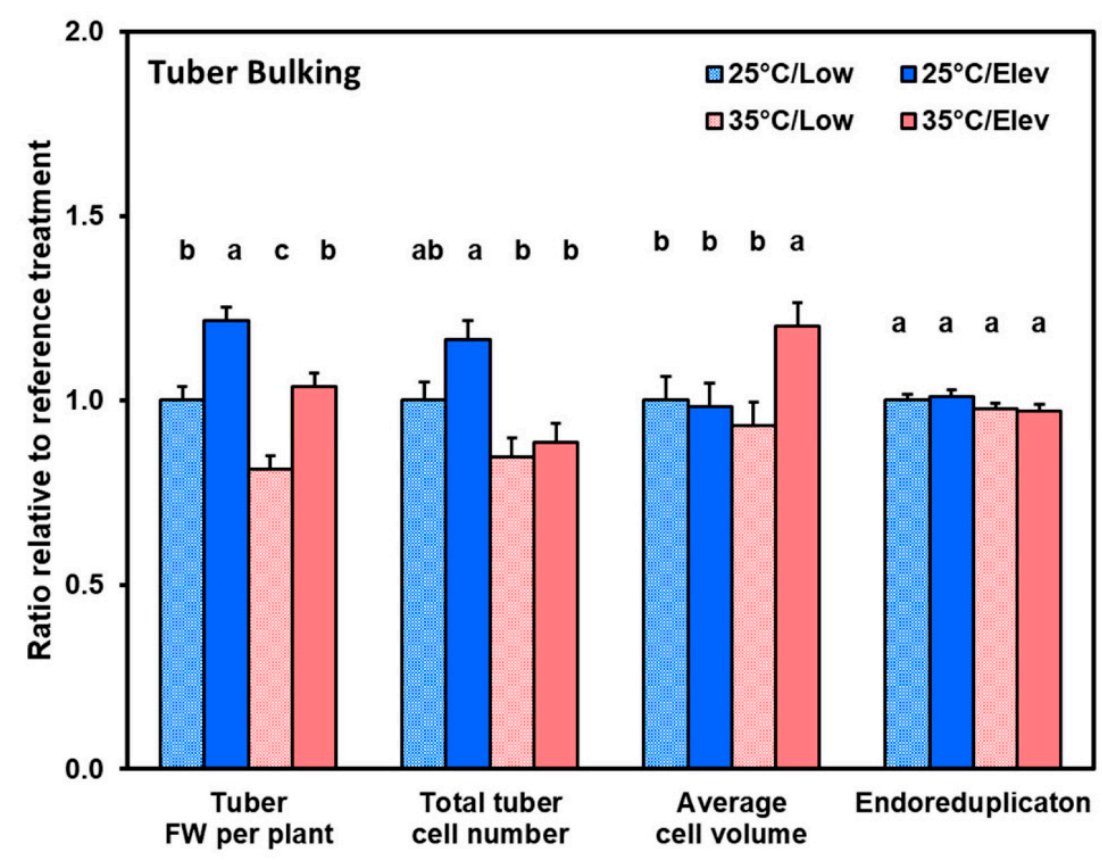

Figure 5. Relative increase in tuber properties with respect to $25^{\circ} \mathrm{C} / \mathrm{Low}_{\mathrm{CO}_{2}}$ control in response to temperature $\left(25\right.$ or $\left.35^{\circ} \mathrm{C}\right)$ or $\mathrm{CO}_{2}$ treatments $\left(\mathrm{Low}_{\mathrm{CO}_{2}}\right.$ or $\left.\mathrm{Elev}_{\mathrm{CO}_{2}}\right)$ at the tuber bulking stage. Tuber weight, and tuber cell number were summed for each plant and represent the increments of tuber fresh-weight growth and cell proliferation during the treatment periods. Data are expressed relative to the $25{ }^{\circ} \mathrm{C} /$ Low $_{\mathrm{CO}_{2}}$ reference which was: $529 \mathrm{~g}$ tuber fresh weight plant ${ }^{-1}, 6.12 \times 10^{8}$ tuber cells plant ${ }^{-1}, 1.17 \times 10^{6} \mathrm{\mu m}^{3}$ average tuber cell volume, and $48.2 \%$ average proportion of tuber cells in endoreduplication categories ( $\geq 8 \mathrm{C}$ nuclear DNA content). See Materials and Methods for details. Bars represent averages \pm SEM of 6 replicates; values labeled with different letters are significantly $(p \leq 0.05)$ different.

\subsection{The Effects of High Temperature and Elevated $\mathrm{CO}_{2}$ on Sugar Levels and Invertases 2.4.1. Sugars}

Given the evidence that cell proliferation in tubers responded substantially to treatments, we considered the hypothesis that $\mathrm{CO}_{2}$ and temperature treatments could affect photosynthate supply or consumption in the phloem-rich zone of tubers. Phloem-containing perimedullar-zone tissues were sampled to provide an indication of carbohydrate status in the region of abundant phloem and rapid cell proliferation. At the tuber initiation stage with elevated $\mathrm{CO}_{2}$, high temperature treatment decreased hexose (glucose + fructose) concentrations (Figure 6a). A decrease in sugar concentration would be expected if high temperature increases the rate of metabolism and use of sugar. However, high temperature increased sucrose concentration at tuber initiation (Figure 6b), suggesting that high temperature did not have a net effect on sugar import/utilization, but might affect conversion of one form to the other. There were no treatment effects on sugars at the tuber bulking stage. Trends in sugar concentrations were toward higher values in elevated $\mathrm{CO}_{2}$, though the differences were not significant $(p \leq 0.05)$. This finding suggests that the conversion of sucrose to hexoses might be affected by the treatments.

\subsubsection{Invertases}

To evaluate whether treatments affected enzymes for converting imported sucrose into hexoses, we measured cell-wall-bound (CWB) and soluble invertase activities in tubers. Activities of CWB and soluble invertases were analyzed in perimedullary zones where phloem is abundant and is delivering photosynthate to growing tissues. In the elevated $\mathrm{CO}_{2}$ treatment at tuber initiation, and at both $\mathrm{CO}_{2}$ treatments at tuber bulking, $\mathrm{CWB}$ invertase activity was slightly decreased in response to high temperature (Figure 7a). Though slight, 
the direction of this inhibition is consistent with it playing a role in the observed increase in sucrose and decrease in hexose in response to high temperature (Figure 6a,b). In contrast, at tuber initiation with low temperature, the elevated $\mathrm{CO}_{2}$ treatment increased both CWB invertase and soluble invertase activity (Figure $7 \mathrm{a}, \mathrm{b}$ ). The direction of this stimulation of invertase activity is consistent with it playing a role at low temperature for maintaining low sucrose and a tendency for higher hexose in response to elevated $\mathrm{CO}_{2}$ (Figure 6).

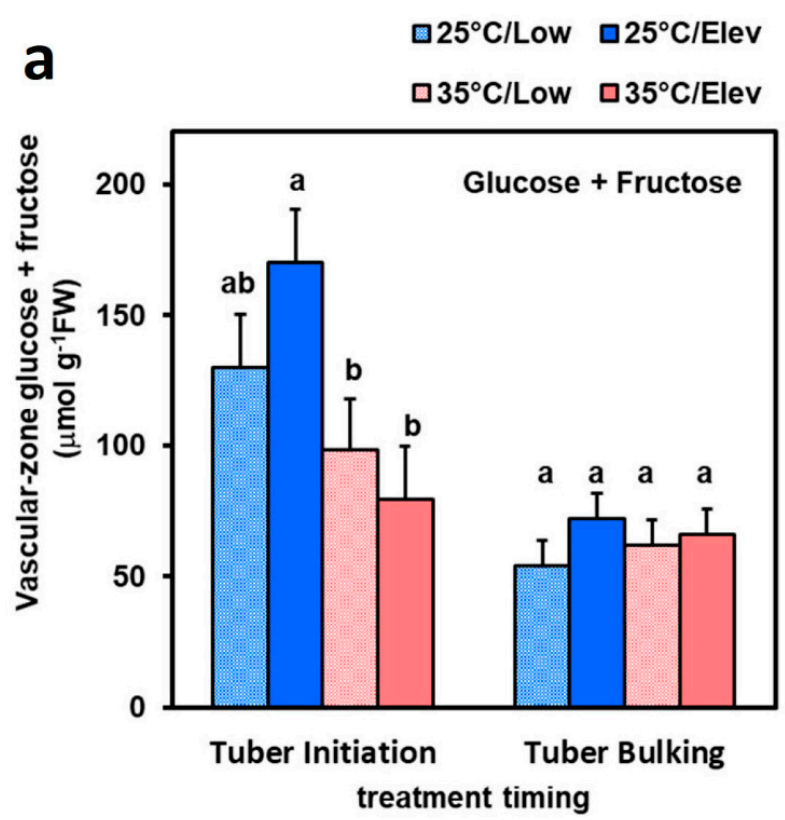

b

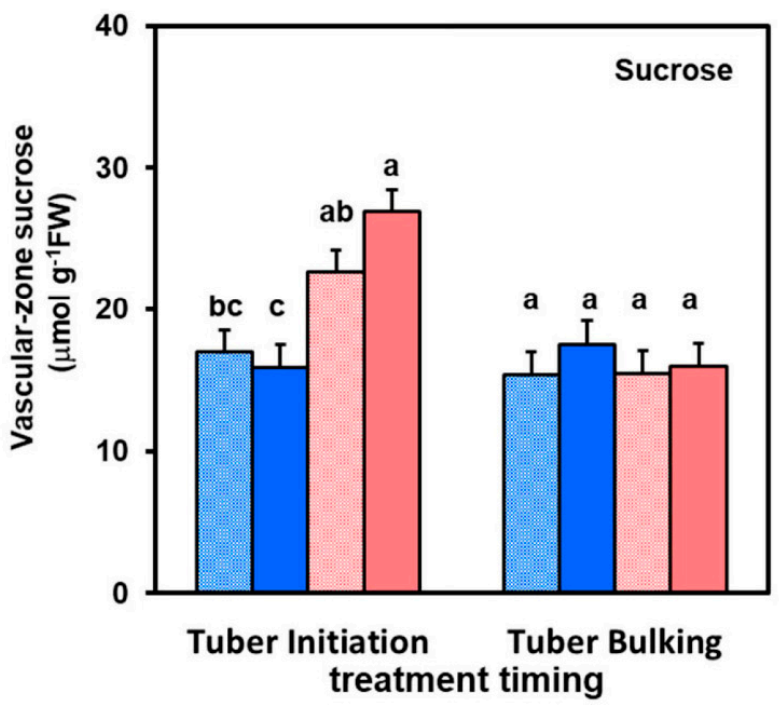

Figure 6. Tuber phloem-rich perimedullary-zone hexose (glucose + fructose) (a) and sucrose (b) in plants exposed to temperature $\left(25\right.$ or $\left.35^{\circ} \mathrm{C}\right)$ or $\mathrm{CO}_{2}\left(\mathrm{Low}_{\mathrm{CO}_{2}}\right.$ or $\left.\mathrm{Elev}_{\mathrm{CO}_{2}}\right)$ treatments at the tuber initiation stage (left of each figure) or tuber bulking stage (right). Plants were harvested after exposure to treatments for 2 weeks. Bars represent averages $\pm \mathrm{SEM}$ of 6 replicates; values labeled with different letters are significantly $(p \leq 0.05)$ different.

a

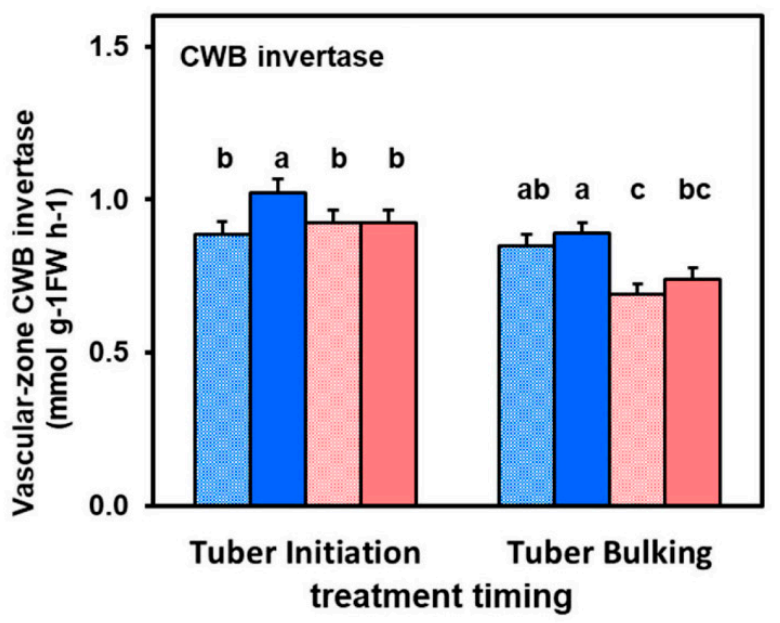

b

$\square 25^{\circ} \mathrm{C} /$ Low $\square 25^{\circ} \mathrm{C} /$ Elev $\square 35^{\circ} \mathrm{C} /$ Low $\quad \square 35^{\circ} \mathrm{C} /$ Elev

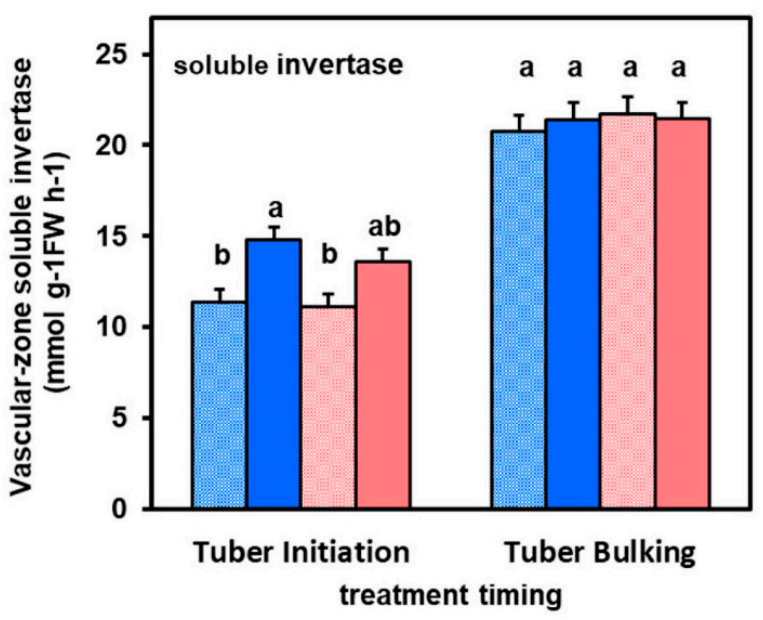

Figure 7. Tuber phloem-rich perimedullary-zone (a): cell wall bound (CWB) acid invertase activity and (b): soluble acid invertase activity in plants exposed to temperature $\left(25\right.$ or $\left.35^{\circ} \mathrm{C}\right)$ or $\mathrm{CO}_{2}\left(\mathrm{Low}_{\mathrm{CO}_{2}}\right.$ or $\left.\mathrm{Elev}_{\mathrm{CO}_{2}}\right)$ treatments at the tuber initiation stage (left of each figure) or tuber bulking stage (right). Plants were harvested after exposure to treatments for 2 weeks. Bars represent averages \pm SEM of 6 replicates; values labeled with different letters are significantly $(p \leq 0.05)$ different. 


\section{Discussion}

\subsection{Elevated Atmospheric $\mathrm{CO}_{2}$ Effect on Whole Plant Biomass Accumulation}

The current findings indicated that two-week treatments involving elevated atmospheric $\mathrm{CO}_{2}$ concentration at $25^{\circ} \mathrm{C}$ increased dry matter accumulation rate by about $30 \%$. This is consistent with previous findings involving short-term elevated $\mathrm{CO}_{2}$ treatments which have been conducted in growth chambers and controlled environments $[27,28]$. However, studies involving long-term exposure to elevated $\mathrm{CO}_{2}$ in open-top and FACE experiments have indicated that such increases in whole-plant photosynthesis are not generally sustained, such that benefit from $\mathrm{CO}_{2}$ enrichment is typically only about half as much in the long term $[11,13,14]$. Several factors are involved in this phenomenon, among them partial stomatal closing, limitations in nitrogen supply, and acclimation as plants adjust their development of sink organs in response to an incremental increase in photosynthate availability, and feedback inhibition of photosynthesis $[7,9,29]$. One of the objectives of the current study was to determine the extent to which potato plants respond to short-term elevated $\mathrm{CO}_{2}$ by stimulating growth of sink organs: tubers, stems, and expanding leaves. In previous full-season studies of potato exposed to $\mathrm{CO}_{2}$ enrichment with open-top chambers, elevated $\mathrm{CO}_{2}$ increased tuber growth and yield, and tubers were preferentially favored, as the partitioning ratio of below-ground to above-ground biomass was increased [15]. Similar findings have been reported for experiments in growth chambers where precise control of the timing of treatments can be achieved [30]. Consistent with this, the current study indicated that elevated $\mathrm{CO}_{2}$ at $25^{\circ} \mathrm{C}$ during tuber initiation increased tuber dry matter accumulation rate (DMAR) by more than $60 \%$, while leaf and stem DMAR was not significantly $(p \leq 0.05)$ affected, even though these organs collectively represented almost two thirds of the sink-organ DMAR (Figure 1). At the tuber bulking phase, when most of plant photosynthate is used for starch storage in tubers, leaves had very low DMAR and stems had a net loss in dry matter, so almost all the benefit from elevated $\mathrm{CO}_{2}$ was obtained by tubers.

\subsection{High Temperature Stress Effect on Whole Plant Biomass Accumulation}

Potato grows optimally in cool climates $\left(15\right.$ to $\left.22^{\circ} \mathrm{C}\right)$ whereas its growth is inhibited in warm or hot environments [10,21,31]. Heat stress can exert detrimental effects on many growth and development processes, so the current studies, involving 2-week treatments at two discrete developmental stages, provide information on the relative susceptibilities of various developmental processes in tubers. Whole-plant dry matter accumulation rate, a measure of whole plant photosynthesis in excess of respiration, was inhibited by high temperature about twice as much at the stage of tuber initiation than at tuber bulking (Table 1; Figures 1 and 2). Similar findings were obtained in studies of elevated temperature under field conditions with temporary transparent chambers in which temperature was increased by about $4{ }^{\circ} \mathrm{C}$ for discrete periods of time [32,33]. Moreover, studies that involved treatments with $35^{\circ} \mathrm{C}$ stress, similar to the present investigation, showed that tuber growth was strongly decreased by exposure to $35^{\circ} \mathrm{C}$ at early phase of tuberization but had a diminishing effect at later stages [26]. In contrast, in a greenhouse study to test the effect of high temperature $\left(30^{\circ} \mathrm{C}\right)$ before tuber initiation versus after tubers had begun bulking, both treatments reduced tuber growth to a similar extent [34]. However, this experiment involved plants that were exposed starting at the date of planting, prior to exposure to tuber-inducing photoperiods, whereas in the current study, plants were first grown with long days, which is a non-inductive photoperiod, then tuber induction was begun at a discrete experimentally determined time. To separate high temperature effects on aboveground and below-ground plant parts, investigators have used growth chambers with root-zone temperature control [25]. After tuber induction, high temperature whole-plant or below-ground treatments both resulted in a reduction in tuber growth and decreased photosynthetic rates [25]. This suggests that communication of root-zone environment or sink-strength status is conveyed to leaves and this may determine the extent to which plant biomass is diminished. Hence, potato response to high temperature appears to depend 
on differences in sensitivity of various plant parts and of the developmental processes at different stages.

Amelioration of high temperature effects by Elevated $\mathrm{CO}_{2}$. In the current study, the percentage inhibition of dry matter accumulation rate (DMAR) by high temperature was somewhat greater in $\mathrm{Low}_{\mathrm{CO}_{2}}$ than in $\mathrm{Elev}_{\mathrm{CO}_{2}}$ treatments (56 and $35 \%$, respectively, at tuber initiation; and 32 and $15 \%$, respectively, at tuber bulking), consistent with earlier findings [33]. In several studies, elevated $\mathrm{CO}_{2}$ has been found to partly ameliorate high temperature stress $[35,36]$. Although the $35{ }^{\circ} \mathrm{C}$ environment decreased both tuber and whole plant DMAR at both tuber initiation and tuber bulking stages (Figures 1 and 2), the elevated $\mathrm{CO}_{2}$ treatment $\left(35^{\circ} \mathrm{C} / \mathrm{Elev}_{\mathrm{CO}_{2}}\right)$ at tuber initiation eased some of the impact of heat stress so that the DMAR of tubers and whole plants recovered to rates comparable to the normal treatment $\left(25^{\circ} \mathrm{C} / \operatorname{Low}_{\mathrm{CO}_{2}}\right)$. At tuber bulking, elevated $\mathrm{CO}_{2}$ eased most of the heat stress, such that tuber DMAR at $35^{\circ} \mathrm{C} / \mathrm{Elev}_{\mathrm{CO}_{2}}$ was mid-way between $25^{\circ} \mathrm{C} / \mathrm{Low}_{\mathrm{CO}_{2}}$ and $25^{\circ} \mathrm{C} /$ Elev $_{\mathrm{CO}_{2}}$.

\subsection{Tuber Growth and Development}

\subsubsection{High Temperature Effects on Components of Tuber Development}

Both tuber cell proliferation and cell expansion (and associated organelle and enzyme development) are needed to develop starch storage capacity for tuber bulking in potato tubers [37]. In previous studies, high temperature suppressed tuber initiation so that tuber numbers per plant were decreased $[33,38,39]$. Consistent with this, we found that tuber numbers were decreased by high temperature when applied at tuber initiation (Figure 3). However, the lower number of tubers may have been due, in part, to the poorer cell division and expansion growth of tubers at high temperature (Figure 4) such that more of the initiated tubers were smaller than the $1 \mathrm{~cm}$ diameter cutoff used for tuber counts. Outcomes similar to this were observed in studies with other treatments that were unfavorable to tuber development and growth, such as shade and long-day photoperiods during tuber bulking $[30,40]$. Moreover, in the present study photoperiod was switched from 14 to $10 \mathrm{~h}$ day length, which provides a very strong tuber inductive signal that may have been sufficient to overcome inhibitory influences due to high temperature [41-44].

\subsubsection{Elevated $\mathrm{CO}_{2}$ Effects on Components of Tuber Development}

We obtained data on three components of early tuber development: cell proliferation, cell expansion, and post-mitotic DNA endoreduplication (Figures 3 and 4). At the tuber initiation stage, with $25^{\circ} \mathrm{C}$, elevated $\mathrm{CO}_{2}$ had a substantial stimulative effect on cell proliferation such that tuber cell numbers in the elevated $\mathrm{CO}_{2}$ treatment were $62 \%$ greater than with the corresponding low $\mathrm{CO}_{2}$ control (Figure 4). In contrast, cell volume and the proportion of cells that had undergone endoreduplication were unaffected. Cell proliferation continued during the tuber bulking stage and cell numbers responded to $\mathrm{Elev}_{\mathrm{CO}_{2}}$ in proportion to tuber weight, while average cell volumes and endoreduplication were not affected (Figure 5). These data are in agreement with previous studies which have shown that cell proliferation is highly responsive to elevated $\mathrm{CO}_{2}$ while cell expansion growth is less responsive at the early phase of tuber development [30]. Transcriptome studies on potato tubers show that genes associated with cell division are highly upregulated during tuber initiation [45].

\subsubsection{Sugar Signaling in Tuber Development}

It is plausible that sugar status in tubers serves as a component of signaling pathways for stimulating enhanced growth in the tubers. At both tuber initiation and tuber bulking, high temperature decreased tuber dry matter (Figures 1 and 2) and fresh weight (Figures 4 and 5) growth. The percentage inhibition at each stage was approximately the same as that for respective whole-plant DMAR, so it is plausible that the inhibitory response in tubers involved photosynthate status as a cue. This interpretation is also supported by the approximately similar pattern of $\mathrm{CO}_{2}$ benefit in tubers compared with that in whole 
plants in response to the $\mathrm{Elev}_{\mathrm{CO}_{2}}$ treatments, although the magnitude of response was greater in tubers than leaves and stems, as discussed above. Studies have identified sugar signaling in potato tubers that regulate patatin storage-protein synthesis [46] and expression of starch pathway enzymes $[25,47,48]$, which are thought to involve sucrose sensing. Consistent with this, when the levels of Trehalose-6-phosphaste (T6P), a sugar-signaling metabolite, was elevated with tuber-specific overexpression of the T6P synthase, or lowered with expression of T6P phosphatase, expression of genes involved in tuber cell proliferation were affected [47]. Studies have shown linkages between sugar signaling pathways and enhanced cell proliferation [49]. In the current study, tuber hexose concentrations tended to increase in the $25^{\circ} \mathrm{C} / \operatorname{Elev}_{\mathrm{CO}_{2}}$ treatment while sucrose was unaffected (Figure 6). Invertase activities were increased in response to $\mathrm{Elev}_{\mathrm{CO}_{2}}$ (Figure 7), consistent with potential involvement in increasing hexose levels and sugar signaling through a hexose signaling pathway [50]. In tomato (Solanum lycopersicum) fruit, evidence from gene silencing indicates that cell wall invertase is essential for sugar signaling and development [51]. While sugar signaling has been studied with respect to potato tuber carbon flux and starch synthesis, it merits further attention with respect to regulation of cell proliferation.

Contrary to the general pattern with $\mathrm{Elev}_{\mathrm{CO}_{2}}$, in the high temperature treatments, at both tuber initiation and tuber bulking, partial amelioration provided by elevated $\mathrm{CO}_{2}$ was substantially due to enhanced cell expansion in the high temperature treatments, whereas cell expansion was not involved in the normal temperature treatments (Figures 4 and 5). In studies of the effects of shade on tuber development, the extent of endoreduplication usually increased where average cell volume was higher [40]. However, in the current study, even though high temperature enhanced cell expansion, it did not affect endoreduplication (Figures 4 and 5). Endoreduplication is common in plants, and in the present study a high proportion of cells were endoreduplicated to nuclear DNA contents $\geq 8 \mathrm{C}$; they were 35 and $49 \%$ at tuber initiation and tuber bulking, respectively. The roles of endoreduplication are still a matter of speculation, though in other plant systems it has been suggested that endoreduplication has a role in stress response [52]. In the present system there was no evidence for an endoreduplication response to $\mathrm{Elev}_{\mathrm{CO}_{2}}$ or high temperature. So, the mechanism by which environment affects tuber growth and development may be different from that involved in other systems.

\subsection{Global Climate Change}

In relation to global climate change, the current study provides insight into potato's sensitivity to various combinations of $\mathrm{CO}_{2}$ and temperature at two discrete developmental phases. In the field, although elevated $\mathrm{CO}_{2}$ is a constant condition throughout a crop season, high temperature stress often occurs for relatively short periods of time, such as one or several days. Given the short time over which heat stress episodes commonly occur in the field, it is of interest to determine whether there are particular stages of potato development that are more sensitive to heat stress. Evaluations of simulation models for potato agronomic responses and global climate change indicate that model variation is modest for predicted $\mathrm{CO}_{2}$ but is particularly uncertain for temperature [5]. This suggests that more knowledge about the nature of heat susceptibility in potato would be valuable in guiding future efforts to improve the crop genetically and to optimize management $[12,21,53]$. In regard to whole plant DMAR, the current studies indicate that the tuber initiation stage may be somewhat more sensitive to stress than tuber bulking. This may be a consequence of the considerably greater sensitivity of cell proliferation and organelle developmental processes at tuber initiation, whereas starch accumulating cells at tuber bulking may be more robust and less responsive to stress. Moreover, plants have numerous feedbacks in their regulatory systems such that changes in tuber sink capacity can provide feedback regulation of photosynthesis [25]. 


\section{Materials and Methods}

\subsection{Plant Material}

Potato plants (cv. Katahdin) were grown from tuber cuttings in a greenhouse with 14 h supplemental lighting and were watered with nutrient solution (Peter's 15-16-17 fertilizer, W.R. Grace and Co., Fogelsville, PA, USA) which supplied the following elemental nutrients: $33 \mathrm{mg} \mathrm{L}^{-1}$ of $\mathrm{NO}_{3}-\mathrm{N}, 86 \mathrm{mg} \mathrm{L}^{-1}$ of $\mathrm{NH}_{4}-\mathrm{N}, 42 \mathrm{mg} \mathrm{L}^{-1}$ of urea-N, $74 \mathrm{mg} \mathrm{L}^{-1}$ of $\mathrm{P}$, $151 \mathrm{mg} \mathrm{L}^{-1}$ of K. Pots $(6 \mathrm{~L})$ contained peat, vermiculite, and perlite $(1: 1: 1 \mathrm{v} / \mathrm{v} / \mathrm{v})$ with $3 \mathrm{~g}$ of pulverized limestone, $17 \mathrm{~g}$ of $\mathrm{CaSO}_{4}, 21 \mathrm{~g}$ of powdered $\mathrm{FeSO}_{4}, 0.5 \mathrm{~g}$ of fritted trace elements (Peters FTE 555, Scotts Co., Marysville, OH, USA), and $1.5 \mathrm{~g}$ of wetting agent (AquaGro G, Aquatrols, Pennsauken, NJ, USA). After two weeks, young plants were trimmed to include one shoot and re-sown in new $12 \mathrm{~L}$ pots with one plant/pot. After transplanting, plants were grown in the greenhouse for an additional 4 weeks, then the plants were transferred to four matched growth chambers where short days ( $10 \mathrm{~h}$ photoperiod) were imposed to initiate tuber formation, as described below. Nutrient solution and watering regime were the same as in the greenhouse.

On the day that plants were transferred to growth chambers for imposition of temperature $\times \mathrm{CO}_{2}$ treatments, plants from a set of uniform material were randomly assigned to the treatments, as described below; concurrently, a subset was designated for immediate harvest at time $=0$ for estimating the dry matter of plants parts at the onset of treatments.

\subsection{Temperature and $\mathrm{CO}_{2}$ Control}

Controlled-environment chambers (Model CEL-63-10, Sherer Inc, Marschall, MI, USA) had interior dimension of $112 \times 74 \mathrm{~cm}$ (width $\times$ depth) and $600 \mu \mathrm{mol}$ photons (photosynthetically active radiation, $400-700 \mathrm{~nm}) \mathrm{m}^{-2} \mathrm{~s}^{-1}$ at the top of the canopy, supplied by fluorescent lamps. Temperature regime was $25 / 18{ }^{\circ} \mathrm{C}$ (day/night) in the normal temperature treatment and $35 / 25^{\circ} \mathrm{C}$ (day/night) in the high temperature treatment. $\mathrm{CO}_{2}$ treatments were either $700 \mu \mathrm{mol} \mathrm{CO} \mathrm{Col}^{-1}$ air (elevated $\mathrm{CO}_{2}$ ) or between 350 and $400 \mu \mathrm{mol} \mathrm{CO}$ $\mathrm{mol}^{-1}$ air (low $\mathrm{CO}_{2}$ ). Chamber $\mathrm{CO}_{2}$ concentration was monitored with a calibrated infrared gas analyzer [30]. The four growth chambers were used to impose a $2 \times 2$ matrix of temperature $\times \mathrm{CO}_{2}$ treatments at two stages of development: (1) during the first 2 weeks after switch from 14 to $10 \mathrm{~h}$ days (weeks after short d; WASD), which stimulates tuber production [hereinafter described as the tuber initiation stage (TI)], or (2) during the next two weeks after switch to short days, when starch accumulation predominates [hereinafter described as the tuber bulking (TB) stage]. Plants for the tuber bulking treatments were first given a short-day (10 h photoperiod) treatment for two weeks in chambers at the normal conditions of $25 / 18^{\circ} \mathrm{C}$ (day/night) and low $\mathrm{CO}_{2}$.

\subsection{Tuber Sampling Method}

To representatively sample tubers for analyses, all tubers within each plant were characterized into three groups by size, each group containing about one third of the tuber fresh biomass in the entire plant. The grouping started by ranking tubers within a plant by size and, starting with the largest tuber, assigning it to the largest size-category, then continuing to the next smaller tuber until the sum of tuber fresh biomass in the category accounted for about one third of the tuber biomass of the entire plant. In this way, at least two tubers were chosen for this size category. Then tubers were assigned to the next size category until the summed biomass in each of the three categories accounted for one third of the total. In each category, three tubers (or two, depending on availability) were randomly chosen for sugar levels or enzymes activities determination.

\subsection{Assay Methods}

From representative tubers, two cores, longitudinal and transverse, were immediately withdrawn with a $0.5 \mathrm{~cm}$ diameter cylindrical borer and fixed in ethanol/acetic acid (3:1) solution for flow cytometry. Then the apical-bud end (rose end) of the tuber was cut off $1 \mathrm{~cm}$ proximal from the apex, and a $0.5 \mathrm{~cm}$ thick slice was obtained from the apical end, 
frozen in liquid nitrogen, and stored at $-20{ }^{\circ} \mathrm{C}$ for further determination of sugars and related enzyme activities. Leaves, stems, and remaining portions of tubers were dried at $50{ }^{\circ} \mathrm{C}$ to constant weight and weighed. Tuber dry weights were corrected for the fresh weight removed for cell cytometry and enzyme activity.

For flow cytometry analysis, core slices were digested with $0.5 \%(w / v)$ pectinase (EC 3.2.1.15, MP Biomedicals, Solon, OH, USA) for $18 \mathrm{~h}$ without shaking at $37^{\circ} \mathrm{C}$, then cooled in a $4{ }^{\circ} \mathrm{C}$ refrigerator overnight before mechanically disrupting cell walls and releasing nuclei into the medium. After about $18 \mathrm{~h}$ of shaking $(150 \mathrm{rpm})$ the tubers were stored in a $4{ }^{\circ} \mathrm{C}$ refrigerator then filtered through nylon-mesh fabric with $100 \mu \mathrm{m}$ openings (Nitex, Teco Inc, Briarcliff Manor, NY, USA). The DNA-binding fluorochrome propidium iodide was added to the filtrate to a final concentration of $90 \mu \mathrm{M}$ in a $10 \mathrm{mM}$ Tris- $\mathrm{HCl}$ buffer ( $\mathrm{pH}$ 7.4). A $100 \mu \mathrm{L}$ aliquot of filtrate was counted by flow cytometry using either a FACScan analyzer (Becton Dickinson, Mountain View, CA, USA), or an Epic Profile (Coulter Electronics, Hialeah, FL, USA) operating with an argon-neon laser (488 nm).

For determination of sugars and related enzymes, $0.5 \mathrm{~cm}$ diameter disks were cut out from the zone rich in vascular bundles in the perimedullary zone near the perimedulla/cortex interface of slices with a cylindrical borer and then homogenized with $50 \mathrm{mM}$ Hepes-KOH (pH 7.4) buffer (tissue:buffer 1:2(w/v)) containing $5 \mathrm{mM} \mathrm{MgCl}_{2}, 1 \mathrm{mM}$ EGTA, $1 \mathrm{mM}$ EDTA, $40 \%(v / v)$ glycerol, $0.1 \%$ bovine serum albumin, $0.5 \mathrm{mM}$ dithiotheritol and $2 \%$ insoluble polyvinylpyrrolidone and stored at $-20{ }^{\circ} \mathrm{C}$. Ten microliter aliquots of supernatant were mixed with $90 \mu \mathrm{L}$ ethanol and stored for sugar assay. The concentrations of glucose, fructose and sucrose were determined using an enzyme-coupled assay based on hexokinase (EC 2.7.1.1, 0.14 unit) and glucose-6-phosphate dehydrogenase (EC 1.1.1.49, 0.07 unit), and using phosphoglucoisomerase (EC 5.3.1.9, 0.2 unit) and invertase (EC 3.2.1.26, 80 units) for fructose and sucrose interconversions [54].

Acid invertase activities were determined in the sucrose hydrolysis direction. For soluble acid invertase, $0.5 \mathrm{~mL}$ of buffer-extract was centrifuged at $16,000 \times g$ and desalted on a Sephadex G-25M to obtain enzyme extract. For cell-wall-bound acid invertase, $0.5 \mathrm{~mL}$ of buffer-extract was centrifuged at $16,000 \times g$ and, then, the pellet was resuspended in $1 \mathrm{~mL}$ of $1 \mathrm{M} \mathrm{NaCl}$ and incubated at $4{ }^{\circ} \mathrm{C}$ at least $12 \mathrm{~h}$ for salt extraction. After centrifugation at $16,000 \times g$, the salt extract was desalted on a Sephadex G-25M to obtained enzyme extract. Both soluble and cell-wall-bond acid invertase activities were determined by mixing enzyme extract $(150 \mu \mathrm{L})$ with $50 \mu \mathrm{L}$ of $1 \mathrm{M}$ sucrose to start the enzyme reaction. The reaction was incubated for $75 \mathrm{~min}$ at $24^{\circ} \mathrm{C}$ and the glucose + fructose produced was assayed as before [54]. All enzyme assays were linear with time and the amount of enzyme extract added.

\subsection{Data Analysis}

The experiments were conducted in three batches with two plants in each ( 6 biological replicates). A plant was considered an experimental unit. Each batch contained a complete set of treatments, which were randomly assigned to four matched chambers set at the two $\mathrm{CO}_{2}$ concentrations and temperatures (a $2 \times 2$ set of treatments), as described above. Data were modeled using a simple linear model with batch, temperature treatment $(\mathrm{T})$, $\mathrm{CO}_{2}$ treatment, and $\mathrm{T} \times \mathrm{CO}_{2}$ interaction as sources of variation. Analysis of variance was conducted in R version 3.6.0 [55] using the $l m$ function. Tukey HSD multiple-range significant-difference tests were used for multiple comparisons.

\section{Conclusions}

The current study elucidated the effects of elevated $\mathrm{CO}_{2}$ and high temperature on potato tuber development at two stages: tuber initiation and tuber bulking. While wholeplant dry matter accumulation rate was increased by elevated $\mathrm{CO}_{2}$ about $30 \%$ at both stages, the responses of plant parts differed considerably. At the tuber initiation stage, and at normal day-time temperature of $25{ }^{\circ} \mathrm{C}$, elevated $\mathrm{CO}_{2}$ increased tuber dry matter accumulation rate by more than $60 \%$, while leaf and stem DMAR was not affected, 
even though these organs collectively represented almost two thirds of the sink-organ DMAR. At the tuber bulking phase, when most of plant photosynthate is used for starch storage in tubers, leaves had very low DMAR and stems had a net loss in dry matter, so almost all the benefit from elevated $\mathrm{CO}_{2}$ was obtained by tubers. The extent to which high temperature stress affected plant growth and sink development differed considerably between stages. Whole-plant dry matter accumulation rate, was inhibited by high temperature treatment about twice as much at the stage of tuber initiation than at tuber bulking. In contrast to $\mathrm{CO}_{2}$ effects at $25^{\circ} \mathrm{C}$, where tubers primarily benefited, at high temperature stress, elevated $\mathrm{CO}_{2}$ benefitted leaf and stem growth in addition to tuber growth, and hence partially ameliorated high temperature inhibition. This suggests that growing plant parts have a development window within which they are capable of responding to improved photosynthate supply. At the tuber initiation stage, with $25^{\circ} \mathrm{C}$, elevated $\mathrm{CO}_{2}$ had its primary effect on cell proliferation such that tuber cell numbers in the elevated $\mathrm{CO}_{2}$ treatment were $62 \%$ greater than with the corresponding low $\mathrm{CO}_{2}$ control. In contrast, cell volume and the proportion of cells that had undergone endoreduplication were unaffected. These findings indicate that the tuber initiation stage and cell division process are particularly responsive to elevated $\mathrm{CO}_{2}$ and high temperature stress. To fully understand impacts of climate change and to develop improved crops, attention should be paid to the timing of high-temperature stress episodes with respect to this stage.

Supplementary Materials: The following are available online at https://www.mdpi.com/article/10 .3390 / plants10050871/s1, Suppl. Figure S1. Distribution of whole-plant tuber production among individual tuber size-classes in plants exposed to temperature $\left(25\right.$ or $\left.35{ }^{\circ} \mathrm{C}\right)$ or $\mathrm{CO}_{2}$ treatments $\left(\right.$ Low $_{\mathrm{CO}_{2}}$ or Elev $_{\mathrm{CO}_{2}}$ ). (a) Tuber initiation stage; (b) tuber bulking stage. Plants were harvested after exposure to treatment for 2 weeks. Tubers exceeding $1 \mathrm{~cm}$ diameter were counted. Tuber production was the sum of tuber fresh weight within the defined size-range category. Data was from 6 replicate plants per stage of development.

Author Contributions: C.-T.C. and T.L.S. contributed to all elements of the work. All authors have read and agreed to the published version of the manuscript.

Funding: This research received no external funding.

Data Availability Statement: The data presented in this study are available on request from the corresponding author.

Acknowledgments: We thank the Section of Crop and Soil Sciences, Cornell University, for growth chamber and lab facilities, and the flow cytometry facilities of the Cornell Institute of Biotechnology and the College of Veterinary Medicine.

Conflicts of Interest: The authors declare no conflict of interest.

\section{References}

1. IPCC. Global Warming of $1.5^{\circ} \mathrm{C}$. An IPCC Special Report on the Impacts of Global Warming of $1.5^{\circ} \mathrm{C}$ above Pre-Industrial Levels and Related Global Greenhouse Gas Emission Pathways, in the Context of Strengthening the Global Response to the Threat of Climate Change, Sustainable Development, and Efforts to Eradicate Poverty. Masson-Delmotte, V., Zhai, P., Pörtner, H.O., Roberts, D., Skea, J., Shukla, P.R., Pirani, A., Moufouma-Okia, W., Péan, C., Pidcock, R., et al., Eds.; 2018. Available online: https://www.ipcc.ch/site/assets/uploads/sites/2/2019/06/SR15_Full_Report_Low_Res.pdf (accessed on 4 April 2021).

2. King, A.W.; Emanuel, W.R.; Post, W.M. Projecting future concentrations of atmospheric carbon dioxide with global carbon cycle models the importance of simulating historical changes. Environ. Manag. 1992, 16, 91-108. [CrossRef]

3. Jarvis, A.; Ramirez-Villegas, J.; Herrera Campo, B.; Navarro-Racines, C. Is cassava the answer to African climate change adaptation? Trop. Plant Biol. 2012, 5, 9-29. [CrossRef]

4. Raymundo, R.; Asseng, S.; Prassad, R.; Kleinwechter, U.; Concha, J.; Condori, B.; Bowen, W.; Wolf, J.; Olesen, J.E.; Dong, Q.; et al. Performance of the SUBSTOR-potato model across contrasting growing conditions. Field Crop. Res. 2017, 202, 57-76. [CrossRef]

5. Fleisher, D.H.; Condori, B.; Quiroz, R.; Alva, A.; Asseng, S.; Barreda, C.; Bindi, M.; Boote, K.J.; Ferrise, R.; Franke, A.C.; et al. A potato model intercomparison across varying climates and productivity levels. Glob. Chang. Biol. 2017, 23, $1258-1281$. [CrossRef]

6. Sun, Q.; Miao, C.; Hanel, M.; Borthwick, A.G.L.; Duan, Q.; Ji, D.; Li, H. Global heat stress on health, wildfires, and agricultural crops under different levels of climate warming. Environ. Int. 2019, 128, 125-136. [CrossRef] 
7. Engineer, C.B.; Hashimoto-Sugimoto, M.; Negi, J.; Israelsson-Nordström, M.; Azoulay-Shemer, T.; Rappel, W.-J.; Iba, K.; Schroeder, J.I. $\mathrm{CO}_{2}$ Sensing and $\mathrm{CO}_{2}$ Regulation of Stomatal Conductance: Advances and Open Questions. Trends Plant Sci. 2016, 21, 16-30. [CrossRef]

8. Drake, B.G.; Gonzalez-Meler, M.A.; Long, S.P. More efficient plants: A consequence of rising atmospheric $\mathrm{CO}_{2}$ ? Annu. Rev. Plant Physiol. Plant Mol. Biol. 1997, 48, 609-639. [CrossRef]

9. Ainsworth, E.A.; Rogers, A. The response of photosynthesis and stomatal conductance to rising $\left[\mathrm{CO}_{2}\right]: \mathrm{Mechanisms} \mathrm{and}$ environmental interactions. Plant Cell Environ. 2007, 30, 258-270. [CrossRef]

10. Timlin, D.; Rahman, S.M.L.; Baker, J.; Reddy, V.R.; Fleisher, D.; Quebedeaux, B. Whole plant photosynthesis, development, and carbon partitioning in potato as a function of temperature. Agron. J. 2006, 98, 1195-1203. [CrossRef]

11. Leakey, A.D.B.; Ainsworth, E.A.; Bernacchi, C.J.; Rogers, A.; Long, S.P.; Ort, D.R. Elevated $\mathrm{CO}_{2}$ effects on plant carbon, nitrogen, and water relations: Six important lessons from FACE. J. Exp. Bot. 2009, 60, 2859-2876. [CrossRef]

12. Tausz, M.; Tausz-Posch, S.; Norton, R.M.; Fitzgerald, G.J.; Nicolas, M.E.; Seneweera, S. Understanding crop physiology to select breeding targets and improve crop management under increasing atmospheric $\mathrm{CO}_{2}$ concentrations. Environ. Exp. Bot. 2013, 88, 71-80. [CrossRef]

13. Long, S.P.; Ainsworth, E.A.; Leakey, A.D.B.; Nosberger, J.; Ort, D.R. Food for Thought: Lower-Than-Expected Crop Yield Stimulation with Rising $\mathrm{CO}_{2}$ Concentrations. Science 2006, 312, 1918-1921. [CrossRef]

14. Miglietta, F.; Magliulo, V.; Bindi, M.; Cerio, L.; Vaccari, F.P.; Loduca, V.; Peressotti, A. Free Air $\mathrm{CO}_{2}$ Enrichment of potato (Solanum tuberosum L.): Development, growth and yield. Glob. Chang. Biol. 1998, 4, 163-172. [CrossRef]

15. Högy, P.; Fangmeier, A. Atmospheric $\mathrm{CO}_{2}$ enrichment affects potatoes: 1 . Aboveground biomass production and tuber yield. Eur. J. Agron. 2009, 30, 78-84. [CrossRef]

16. Manrique, L.A.; Bartholomew, D.P. Growth and Yield Performance of Potato Grown at Three Elevations in Hawaii: II. Dry Matter Production and Efficiency of Partitioning. Crop Sci. 1991, 31, 367-372. [CrossRef]

17. Sage, R.F.; Way, D.A.; Kubien, D.S. Rubisco, Rubisco activase, and global climate change. J. Exp. Bot. 2008, 59, 1581-1595. [CrossRef]

18. Struik, P.C.; Geertsema, J.; Custers, C.-H.M. Effects of shoot; root and stolon temperature on the development of the potato (Solanum tuberosum L.) plant. III. Development of tubers. Potato Res. 1989, 32, 151-158. [CrossRef]

19. Basu, P.S.; Minhas, J.S. Heat tolerance and assimilate transport in different potato genotypes. J. Exp. Bot. 1991, 42, 861-866. [CrossRef]

20. Kaminski, K.P.; Korup, K.; Nielsen, K.L.; Liu, F.; Topbjerg, H.B.; Kirk, H.G.; Andersen, M.N. Gas-exchange, water use efficiency and yield responses of elite potato (Solanum tuberosum L.) cultivars to changes in atmospheric carbon dioxide concentration, temperature and relative humidity. Agric. For. Meteorol. 2014, 187, 36-45. [CrossRef]

21. Singh, B.; Kukreja, S.; Goutam, U. Impact of heat stress on potato (Solanum tuberosum L.): Present scenario and future opportunities. J. Hortic. Sci 2020, 95, 407-424. [CrossRef]

22. Ewing, E.E. Heat stress and the tuberization stimulus. Am. Potato J. 1981, 58, 31-49. [CrossRef]

23. Mohabir, G.; John, P. Effect of temperature on starch synthesis in potato tuber tissue and in amyloplasts. Plant Physiol. 1989, 88, 1222-1228. [CrossRef]

24. Reynolds, M.P.; Ewing, E.E. Effects of high air and soil temperature stress on growth and tuberization in Solanum tuberosum. Ann. Bot. 1989, 64, 241-248. [CrossRef]

25. Hastilestari, B.R.; Lorenz, J.; Reid, S.; Hofmann, J.; Pscheidt, D.; Sonnewald, U.; Sonnewald, S. Deciphering source and sink responses of potato plants (Solanum tuberosum L.) to elevated temperatures. Plant Cell Environ. 2018, 41, 2600-2616. [CrossRef]

26. Rykaczewska, K. The Effect of High Temperature Occurring in Subsequent Stages of Plant Development on Potato Yield and Tuber Physiological Defects. Am. J. Potato Res. 2015, 92, 339-349. [CrossRef]

27. Poorter, $\mathrm{H}$. Interspecific variation in the growth response of plants to an elevated ambient $\mathrm{CO}_{2}$ concentration. Vegetatio 1993, 104, 77-97. [CrossRef]

28. Cure, J.D.; Acock, B. Crop responses to carbon dioxide doubling: A literature survey. Agric. For. Meteorol. 1986, $38,127-145$. [CrossRef]

29. Bryant, J.; Taylor, G.; Frehner, M. Photosynthetic acclimation to elevated $\mathrm{CO}_{2}$ is modified by source: Sink balance in three component species of chalk grassland swards grown in a free air carbon dioxide enrichment (FACE) experiment. Plant Cell Environ. 1998, 21, 159-168. [CrossRef]

30. Chen, C.-T.; Setter, T.L. Response of potato dry matter assimilation and partitioning to elevated $\mathrm{CO}_{2}$ at various stages of tuber initiation and growth. Environ. Exp. Bot. 2012, 80, 27-34. [CrossRef]

31. Midmore, D.J.; Prange, R.K. Growth responses of two Solanum species to contrasting temperatures and irradiance levels relations to photosynthesis dark respiration and chlorophyll fluorescence. Ann. Bot. 1992, 69, 13-20. [CrossRef]

32. Kim, Y.-U.; Lee, B.-W. Differential Mechanisms of Potato Yield Loss Induced by High Day and Night Temperatures During Tuber Initiation and Bulking: Photosynthesis and Tuber Growth. Front. Plant Sci. 2019, 10, 300. [CrossRef] [PubMed]

33. Lee, Y.-H.; Sang, W.-G.; Baek, J.-K.; Kim, J.-H.; Shin, P.; Seo, M.-C.; Cho, J.-I. The effect of concurrent elevation in $\mathrm{CO}_{2}$ and temperature on the growth, photosynthesis, and yield of potato crops. PLoS ONE 2020, 15, e0241081. [CrossRef] [PubMed]

34. Obiero, C.O.; Milroy, S.P.; Bell, R.W. Importance of whole plant dry matter dynamics for potato (Solanum tuberosum L.) tuber yield response to an episode of high temperature. Environ. Exp. Bot. 2019, 162, 560-571. [CrossRef] 
35. Ahmed, F.E.; Hall, A.E.; Madore, M.A. Interactive effects of high temperature and elevated carbon dioxide concentration on cowpea (Vigna unguiculata L. Walp.). Plant Cell Environ. 1993, 16, 835-842. [CrossRef]

36. Wayne, P.M.; Reekie, E.G.; Bazzaz, F.A. Elevated $\mathrm{CO}_{2}$ ameliorates birch response to high temperature and frost stress: Implications for modeling climate-induced geographic range shifts. Oecologia 1998, 114, 335-342. [CrossRef]

37. $\mathrm{Xu}, \mathrm{X}$.; Vreugdenhil, D.; Lammeren, A.A.M.V. Cell division and cell enlargement during potato tuber formation. J. Exp. Bot. 1998, 49, 573-582. [CrossRef]

38. Manrique, L.A.; Bartholomew, D.P.; Ewing, E.E. Growth and yield performance of several potato clones grown at three elevations hawaii usa i. Plant morphology. Crop Sci. 1989, 29, 363-370. [CrossRef]

39. Nooruddin, A.; Mehta, A.N.; Patel, H.R. Tuber production in relation to weather parameters and agrometeorological indices prevailing during different phenological stages of potato crop. J. Indian Potato Assoc. 1995, 22, 22-117.

40. Chen, C.-T.; Setter, T.L. Response of potato tuber cell division and growth to shade and elevated $\mathrm{CO}_{2}$. Ann. Bot. 2003, 91, 373-381. [CrossRef]

41. Dutt, S.; Manjul, A.S.; Raigond, P.; Singh, B.; Siddappa, S.; Bhardwaj, V.; Kawar, P.G.; Patil, V.U.; Kardile, H.B. Key players associated with tuberization in potato: Potential candidates for genetic engineering. Crit. Rev. Biotechnol. 2017, 37, 942-957. [CrossRef]

42. Jackson, S.D. Multiple signaling pathways control tuber induction in potato. Plant Physiol. 1999, 119, 1-8. [CrossRef]

43. Van Dam, J.; Kooman, P.L.; Struik, P.C. Effects of temperature and photoperiod on early growth and final number of tubers in potato (Solanum tuberosum L.). Potato Res. 1996, 39, 51-62. [CrossRef]

44. Wallace, D.; Yan, W. A model of photoperiod $x$ temperature interaction effects on plant development. In Plant Breeding and Whole-System Crop Physiology: Improving Adaptation, Maturity and Yield; CAB International: New York, NY, USA, 1998; pp. 78-98.

45. Kloosterman, B.; De Koeyer, D.; Griffiths, R.; Flinn, B.; Steuernagel, B.; Scholz, U.; Sonnewald, S.; Sonnewald, U.; Bryan, G.J.; Prat, S.; et al. Genes driving potato tuber initiation and growth: Identification based on transcriptional changes using the POCI array. Funct. Integr. Genom. 2008, 8, 329-340. [CrossRef]

46. Yoon, J.; Cho, L.-H.; Tun, W.; Jeon, J.-S.; An, G. Sucrose signaling in higher plants. Plant Sci. 2021, 302, 110703. [CrossRef]

47. Debast, S.; Nunes-Nesi, A.; Hajirezaei, M.R.; Hofmann, J.; Sonnewald, U.; Fernie, A.R.; Börnke, F. Altering Trehalose-6Phosphate Content in Transgenic Potato Tubers Affects Tuber Growth and Alters Responsiveness to Hormones during Sprouting. Plant Physiol. 2011, 156, 1754-1771. [CrossRef]

48. Ferreira, S.J.; Sonnewald, U. The mode of sucrose degradation in potato tubers determines the fate of assimilate utilisation. Front. Plant Sci. 2012, 3, 23. [CrossRef]

49. Wang, L.; Ruan, Y.-L. Regulation of cell division and expansion by sugar and auxin signaling. Front. Plant Sci. 2013, 4, 163. [CrossRef]

50. Li, L.; Sheen, J. Dynamic and diverse sugar signaling. Curr. Opin. Plant Biol. 2016, 33, 116-125. [CrossRef]

51. Liao, S.; Wang, L.; Li, J.; Ruan, Y.-L. Cell Wall Invertase Is Essential for Ovule Development through Sugar Signaling Rather Than Provision of Carbon Nutrients. Plant Physiol. 2020, 183, 1126-1144. [CrossRef]

52. Scholes, D.R.; Paige, K.N. Plasticity in ploidy: A generalized response to stress. Trends Plant Sci. 2015, 20, 165-175. [CrossRef]

53. Bhargava, S.; Mitra, S. Elevated atmospheric $\mathrm{CO}_{2}$ and the future of crop plants. Plant Breed. 2021, 140, 1-11. [CrossRef]

54. Cairns, A.J. Colorimetric microtiter plate assay of glucose and fructose by enzyme-linked formazan production: Applicability to the measurement of fructosyl transferase activity in higher plants. Anal. Biochem. 1987, 167, 270-278. [CrossRef]

55. R_Core_Team. R: A Language and Environment for Statistical Computing. 2017. Available online: https://www.R-project.org/ (accessed on 22 March 2021). 